\title{
Unsur Kepercayaan dan Kearifan Tempatan dalam Memorat Perubatan Tradisional Etnik Murut Tahol di Sabah
}

\section{Elements of Local Beliefs and Wisdom in the Traditional Healing Memorates of the Tahol Murut of Sabah}

\author{
*NORMADIAH NASSIR ${ }^{1}$ \\ LOW KOK ON ${ }^{1}$ \\ ISMAIL IBRAHIM ${ }^{1}$ \\ SUPYAN HUSSIN ${ }^{2}$

\begin{abstract}
${ }^{1}$ Borneo Heritage Research Unit, Faculty of Humanities, Arts and Heritage, Universiti Malaysia
Sabah, 88400 Kota Kinabalu, Sabah, Malaysia

Selangor, Malaysia

*Corresponding author: florenceatun89@gmail.com
\end{abstract} \\ ${ }^{2}$ Faculty of Social Sciences and Humanities, Universiti Kebangsaan Malaysia, 43600 UKM Bangi,
}

Published online: 15 September 2017

To cite this article: Normadiah, N., Low, K.O., Ismail, I. and Supyan, H. 2017. Unsur kepercayaan dan kearifan tempatan dalam memorat perubatan tradisional etnik Murut Tahol di Sabah. KEMANUSIAAN the Asian Journal of Humanities 24(2): 59-88, https://doi.org/10.21315/kajh2017.24.2.3

To link to this article: https://doi.org/10.21315/kajh2017.24.2.3

\begin{abstract}
Abstrak. Memorat ialah sejenis legenda yang diwarisi secara lisan dan dipercayai benar dalam kalangan masyarakat pendukungnya. Ramai pengkaji Barat mahupun tempatan mendapati kisah legenda merakamkan pengetahuan orang terdahulu. Dalam kajian ini, seramai 26 orang informan daripada suku etnik Murut Tahol telah ditemu bual dalam kerja lapangan yang dikendalikan di beberapa buah kampung di daerah kecil Kemabong, Sabah. Siri temu bual ini telah menghasilkan sebanyak 25 buah memorat yang seterusnya dirakamkan, ditranskripsikan dan didokumentasikan. Kajian ini menggunakan kaedah temu bual secara individu dan temu bual secara kumpulan berfokus. Fokus perbincangan makalah ini ialah perkaitan antara kisah memorat dengan perubatan rohani dan fizikal dalam kalangan masyarakat etnik Murut Tahol. Unsur kepercayaan dan kearifan tempatan yang dikenal pasti dalam memorat etnik Murut Tahol turut dianalisis berdasarkan kaedah interpretasi dan perbandingan. Analisis mendapati bahawa etnik Murut Tahol percaya akan mimpi, pelbagai jenis semangat ghaib serta haiwan tertentu yang dianggap dapat membantu mereka mengubati penyakit rohani (seperti kerasukan dan gangguan semangat) dan penyakit fizikal (seperti luka, demam dan sakit perut). Unsur-unsur sedemikian ialah unsur sepunya yang dimiliki etnik peribumi Sabah dan Sarawak, orang Melayu dan bangsa lain di dunia ini. Daripada segi kearifan tempatan pula, etnik Murut Tahol didapati arif dalam mengenal pasti jenis dan ciri-ciri tumbuh-tumbuhan yang sesuai untuk dijadikan ubat. Selain itu, mereka juga mahir dalam menyediakan ubat-ubatan tradisional dan
\end{abstract}


menggunakan sasampui (jampi) dalam mengubati pelbagai jenis penyakit fizikal dan rohani. Kesimpulannya, memorat didapati telah mempengaruhi amalan perubatan tradisional etnik Murut Tahol secara turun-temurun dan secara tidak langsung menonjolkan kearifan tempatan dan kepercayaan terhadap keberkesanan kaedah perubatan yang diwarisi oleh mereka.

Kata kunci dan frasa: memorat, Murut Tahol, perubatan tradisional, kepercayaan, kearifan tempatan

\begin{abstract}
A memorate is a type of legend passed on orally from one generation to another and perceived as truth or real by those who uphold such beliefs. Many Western and local researchers have found legends to be records of the knowledge of people in the past. In this study, 26 Tahol Murut informants were interviewed during field work conducted in several villages located in the Kemabong subdistrict of Sabah. These interviews generated a total of 25 memorates which were recorded, transcribed and documented. This research utilised the in-depth interview and focus group interview methods. The focus of this paper is the relationship between memorates and the physical and spiritual healings of the Tahol Murut ethnic community. The elements of local beliefs and wisdom found in the memorates were analysed based on interpretation and comparison methods. The analysis found that the Murut Tahol people believed in dreams, supernatural beings and certain animals that were perceived as able to assist in the healing of spiritual afflictions (such as spiritual possession and disturbances) and physical illness (such as injury, fever and stomach ache). Such beliefs are universal among the various ethnic groups in Sabah and Sarawak, the Malays and other races as well. In terms of local wisdom, this study found the Tahol Murut skilful at identifying the types and characteristics of plants that had medicinal value. They were also adept in the preparation of various types of traditional medicine and the use of 'sasampui' (a type of spell) in physical and spiritual healing. In conclusion, this study found memorates had significantly influenced the traditional healing practice of the Tahol Murut ethnic community throughout time and invariably reflect the local wisdom and belief in the efficacy of their inherited healing methods.
\end{abstract}

Keywords and phrases: memorate, Tahol Murut, traditional medication, belief, local wisdoms

\title{
Pendahuluan
}

Etnik Murut Tahol merupakan satu daripada 12 subetnik Murut di Sabah. ${ }^{1}$ Kajian mendapati etnik ini berasal dari petempatan di sekitar Sungai Tahol yang terletak di daerah Pensiangan sebelum mereka berpindah ke kawasan-kawasan lain seperti yang ada pada hari ini (Ismail 2007, 72: Pugh-Kitingan 2012, 25; Abdul Hakim 2014, 426). Pengkaji Barat awal seperti Tom Harrison mengaitkan etnik ini dengan golongan pemburu kepala dan hidup secara berkelompok serta berpindah-randah (Ismail 2007, 73). Daripada segi bahasa, Pugh-Kitingan (2012, 59) menjelaskan 
bahawa etnik ini menggunakan bahasa Murut Tahol, iaitu kelompok bahasa terbesar daripada kumpulan Murut di Sabah. Walau bagaimanapun, bahasa yang dituturkan oleh mereka mempunyai dua dialek dan tiga subdialek yang berlainan disebabkan oleh kawasan tempat tinggal mereka yang dipisahkan oleh gunung-ganang. Dalam sistem sosioekonomi pula, etnik Murut Tahol menjalankan sistem pertanian berasaskan penanaman padi bukit yang dilakukan pada setiap tahun. Selain penanaman padi, golongan ini turut mengusahakan tanaman lain seperti ubi kayu dan sayur-sayuran. Golongan lelaki pula memburu haiwan dengan menggunakan anjing manakala golongan wanita mengutip sayur-sayuran dan buah-buahan hutan (Pugh-Kitingan 2012, 62). Daripada aspek amalan dan kepercayaan, etnik Murut Tahol masih berpegang pada adat dan kepercayaan tradisional warisan nenek moyang mereka. Mereka percaya bahawa segala isi dunia ini berasal daripada Aki Kaulung (Pencipta Murut Tahol). Ketika kajian ini dijalankan di daerah kecil Kemabong, Tenom, majoriti golongan etnik Murut Tahol yang berumur lebih daripada 50 tahun ke atas masih bercucuk tanam, berburu dan menangkap ikan. Kebanyakan golongan muda yang berpendidikan telah berkecimpung dalam perkhidmatan kerajaan dan swasta malah sesetengah mereka telah berhijrah ke kawasan bandar. Daripada segi kepercayaan, kira-kira 80 peratus daripada etnik Murut Tahol di daerah kecil Kemabong telah menganut agama Kristian, kirakira 10 peratus beragama Islam dan bakinya masih mengamalkan kepercayaan tradisional. Pada masa ini, majoriti etnik Murut Tahol menetap di daerah Nabawan, Pensiangan, Keningau dan Tenom (temu bual wakil Jawatankuasa Kemajuan dan Keselamatan Kampung di Pejabat Daerah Kecil Kemabong, 8 Julai 2014).

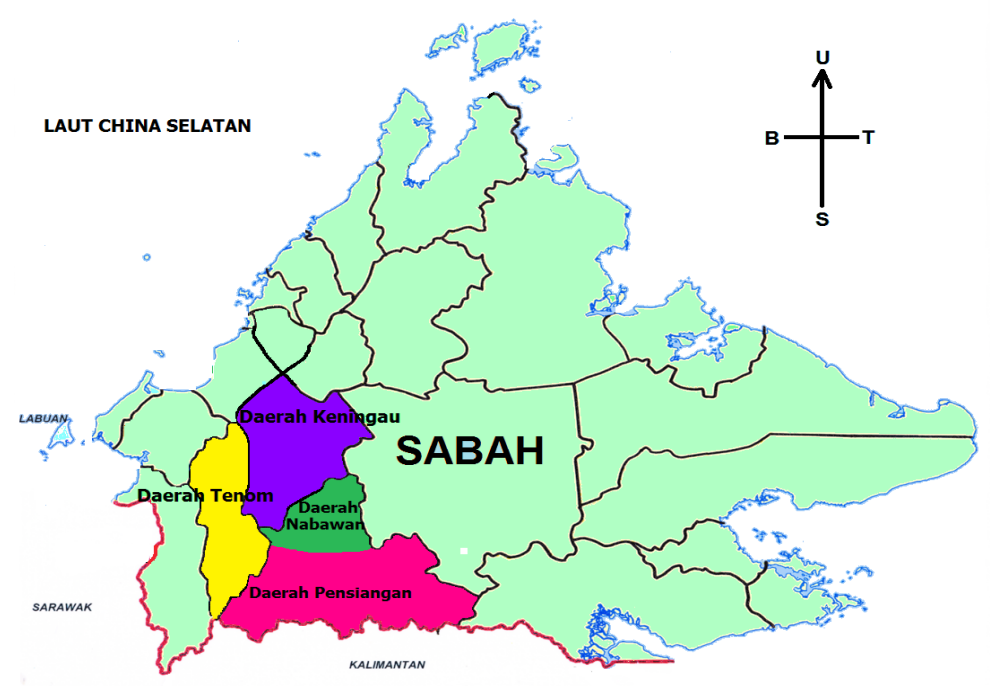

Rajah 1. Peta daerah Tenom, Keningau, Nabawan dan Pensiangan Sumber: Diubah suai daripada https://www.google.com/search?q=peta+daerah+tenom 
Dalam satu kajian lapangan yang telah dilakukan oleh pengkaji di beberapa buah kampung di daerah kecil Kemabong, Sabah, segelintir etnik Murut Tahol didapati masih mewarisi cerita lisan yang berkait rapat dengan aspek perubatan tradisional mereka. Menurut beberapa orang informan dalam kajian ini, banyak jenis cerita yang berhubung dengan hal-hal perubatan sering disampaikan oleh warga tua Murut Tahol kepada anak-anak atau saudara-mara mereka sejak dari dahulu sehinggalah ke hari ini. Semua informan (Lampiran 1) menyatakan bahawa antara cerita yang kerap didengar mereka mengisahkan pengalaman sebenar ibu bapa, datuk nenek atau saudara-mara mereka yang sembuh daripada pelbagai jenis penyakit seperti luka, bengkak atau gatal dan penyakit ganjil yang tertentu.

Daripada segi permasalahan kajian yang timbul, secara turun-temurun, ilmu perubatan tradisional Murut Tahol disebarkan daripada satu generasi kepada satu generasi lain secara lisan, sama ada dalam bentuk cerita lisan ataupun melalui tunjuk ajar. Ilmu perubatan tradisional Murut Tahol seperti ini hanya disebarkan dalam kalangan ahli keluarga terdekat sahaja. Dengan perkataan lain, penyebaran ilmu perubatan tradisional Murut Tahol sedemikian adalah terbatas. Ketika perkhidmatan perubatan moden mula diperkenalkan di daerah kecil Kemabong pada sekitar tahun 1970-an, kebanyakan etnik Murut Tahol masih berpegang kuat pada amalan perubatan tradisional. Disebabkan oleh peredaran zaman dan generasi muda etnik Murut Tahol yang mula menerima pendidikan moden, mereka mula yakin dengan perkhidmatan perubatan moden yang disediakan oleh kerajaan dan tidak begitu bergantung pada amalan perubatan tradisional lagi. Jika diamati, hanya mereka yang dalam lingkungan umur 40 tahun ke atas yang masih mengamalkan perubatan tradisional sehingga hari ini. Permasalahan yang timbul di sini ialah golongan yang masih mengamalkan perubatan tradisional ini tidak lagi menyebarkan ilmu perubatan tradisional kepada ahli keluarganya seperti dahulu. Golongan muda etnik Murut Tahol yang berpendidikan pada hari ini pula sudah tidak berminat untuk mempelajari ilmu perubatan tardisional apatah lagi untuk mendengar cerita seperti mitos dan legenda yang mengandungi ilmu perubatan tradisional. Cerita mitos dan legenda yang disebarkan secara lisan sehingga hari ini mempunyai banyak maklumat penting seperti asal usul perubatan tradisional, jenis-jenis tumbuhan yang sesuai dijadikan ubat-ubatan dan kaedah penyediaan ubat-ubatan tradisional. Oleh yang demikian, kajian ini dijalankan bagi merakamkan dan menganalisis ilmu perubatan tradisional etnik Murut Tahol dalam bentuk memorat (sejenis legenda) bagi memastikan ia terpelihara dan dapat didokumentasikan sebagai rujukan generasi akan datang.

Berdasarkan hasil temu bual bersama informan etnik Murut Tahol, sejumlah 25 buah memorat (definisi akan diberikan kemudian) yang berkait dengan aspek 
perubatan tradisional telah dikumpul. Dalam makalah ini, pengkaji akan memfokus kepada cerita memorat, iaitu sejenis legenda yang berkait rapat dengan perubatan rohani dan perubatan fizikal etnik Murut Tahol secara turun-temurun. Antara aspek penting yang bakal dianalisis adalah pengaruh memorat terhadap amalan perubatan tradisional etnik Murut Tahol, unsur kepercayaan tradisional dan kearifan tempatan yang terkandung di dalamnya. Dengan cara demikian, maklumat penting yang terkandung dalam memorat, unsur kepercayaan dan kearifan tempatan etnik Murut Tahol turun-temurun dapat didedahkan kepada umum.

\section{Sorotan Literatur}

Dalam konteks pengumpulan cerita rakyat, mitos dan legenda secara umum, Woolley (1928) telah menerbitkan lapan buah cerita legenda, sebuah mitos dan dua buah cerita binatang. Walau bagaimanapun, dalam himpunan cerita rakyat mitos dan legenda Woolley ini, kisah legenda yang mempunyai kaitan dengan perubatan tradisional mana-mana etnik peribumi secara langsung tidak dijumpai. Terdapat juga beberapa orang pengkaji lain yang telah memberikan tumpuan terhadap aspek perubatan fizikal dan kerohanian dalam kalangan etnik Murut Tahol. Fung (2003), dalam tulisannya sebagai contoh, telah membincangkan secara umum dunia kerohanian, ritual dan perbomohan etnik Murut Tahol di Sabah. Menurut Fung (2003), etnik Murut Tahol percaya bahawa terdapat banyak jenis semangat yang tidak kelihatan yang menghuni di alam rimba, sungai dan objek-objek tertentu yang boleh mendatangkan pelbagai jenis penyakit rohani kepada manusia. Kesemua jenis semangat tersebut mempunyai nama panggilan tertentu oleh etnik Murut Tahol dan sangat mempengaruhi kehidupan mereka, terutama daripada aspek kerohanian. Kulip (2003, 2005) pula memfokuskan perihal tumbuhtumbuhan yang digunakan secara khusus dalam perubatan tradisional etnik Murut dan Kadazandusun di Sabah. Dalam kajian Kulip $(2003,2005)$, tumbuh-tumbuhan pelbagai jenis yang digunakan secara khusus dalam perubatan tradisional etnik Murut dan Kadazandusun telah didokumentasikan. Walau bagaimanapun, jika diteliti, semua kajian tentang perubatan tradisional etnik Murut yang lepas tidak memberikan tumpuan terhadap cerita lisan yang bersabit dengan perubatan tradisional mereka.

\section{Metodologi dan Kaedah Kajian}

Kajian ini merupakan kajian lapangan dan data dikumpulkan daripada informan Murut Tahol yang menetap di beberapa buah kampung di sekitar daerah kecil Kemabong. Dalam hal ini, Toelken (1996) dan Mohd. Taib (1982) melaporkan bahawa kerja lapangan bagi mengumpul bahan tradisi lisan ialah metodologi 
utama dalam penyelidikan yang berkait dengan bidang foklor (folklore), iaitu segala pengetahuan dan tradisi rakyat. Metodologi ini merangkumi tiga peringkat utama, iaitu peringkat pengumpulan data, dokumentasi hasil kerja lapangan dan penganalisisan data.

Kaedah kajian yang digunakan dalam mengumpul data di lokasi ialah kaedah temu bual secara individu (in-depth interview) dan kaedah temu bual secara kumpulan berfokus (focus group interview). Melalui temu bual secara individu, pengkaji telah pergi ke rumah para informan untuk mendapatkan cerita-cerita lisan daripada mereka. Cerita-cerita lisan pada kebiasaannya mengambil masa agak lama untuk diceritakan kembali oleh seseorang informan, maka melalui kaedah temu bual secara individu ini, seseorang informan dapat menceritakan atau menjelaskan sesuatu perkara secara terperinci dan mendalam. Melalui kaedah temu bual kumpulan berfokus pula, pengkaji telah menjalankan sesi temu bual bersama beberapa orang informan secara serentak dalam satu sesi temu bual yang sama. Dengan menemu bual informan secara kumpulan berfokus - selain dapat mengumpul data daripada beberapa informan - mereka dapat saling bantumembantu mengingatkan dan membetulkan maklumat ataupun sesuatu cerita yang berkait dengan perubatan tradisional sesama mereka. Dalam sesi temu bual yang dikendalikan, segala maklumat dan cerita lisan yang dituturkan oleh informan dirakamkan untuk rekod.

Daripada segi etika kajian, setiap informan yang ditemu bual telah dimaklumi tentang tujuan kajian dijalankan. Pengkaji juga memperoleh persetujuan daripada mereka untuk melaporkan dan menyiarkan maklumat yang diberikan oleh mereka kelak. Sebanyak 26 orang informan yang bersesuaian dengan topik kajian telah dikenal pasti dan ditemu bual. Kesemua mereka ialah pengamal perubatan tradisional Murut. Oleh yang demikian, maklumat kajian yang diperoleh daripada mereka adalah berdasarkan pengalaman mereka sendiri dan dianggap sah daripada segi kajian empirikal. Identiti mereka juga dirahsiakan dan hanya dilabelkan sebagai Informan 1, Informan 2 dan seterusnya (Lampiran 1).

\section{Definisi Legenda dan Memorat}

Dalam kajian sastera rakyat, memorat tergolong sebagai salah satu subgenre legenda. Sebelum memorat didefinisi, ada baiknya istilah legenda diberikan penjelasan terlebih dahulu. Menurut Mohd. Taib (1991, 1) dan Aripin (1996, 15), legenda tergolong dalam salah satu sastera rakyat yang bercorak cerita. Mohd. Taib $(1988,244)$ juga mencatatkan bahawa legenda merupakan cerita-cerita yang dipercayai benar oleh anggota masyarakat. Cerita-cerita legenda lazimnya berkisar tentang tokoh-tokoh tertentu yang pernah wujud dalam kalangan masyarakat dan 
diakui keistimewaannya oleh mereka. Harun Mat Piah $(2003,25)$ dan Low Kok On $(2005,25)$ pula mencatatkan bahawa kisah legenda ialah cerita yang serius, dipercayai benar, mengandungi ciri-ciri luar biasa dan membicarakan perihal tokoh-tokoh suci dan tokoh-tokoh sekular.

Legenda dapat dikategorikan kepada beberapa kategori yang berlainan, antaranya ialah legenda tokoh tempatan, yang biasanya dihubungkan dengan kepahlawanan atau keagamaan; legenda berunsur sejarah serta tanda-tanda alam yang lain; dan legenda yang dihubungkan dengan kepercayaan atau pengalaman seseorang (memorat) (Aripin 1996, 57-58). Secara spesifik, memorat menceritakan pengalaman manusia yang dipercayai benar. Danandjaya $(2002,71)$ pula mencatatkan bahawa memorat merupakan kisah yang benar-benar terjadi dan pernah dialami oleh seseorang. Kisah yang diceritakan ialah pengalaman peribadi seseorang dan 'pengalaman' yang dimaksudkan ini mengandungi banyak motif tradisional (Danandjaya 2002, 71). Dalam makalah ini, cerita-cerita legenda yang telah diperoleh pengkaji ialah memorat belaka, iaitu cerita yang mengisahkan pengalaman sebenar etnik Murut Tahol yang berkait dengan perubatan rohani dan fizikal secara turun-temurun.

\section{Proses Pengumpulan Data}

Dalam mengumpul maklumat yang berkait dengan perubatan tradisional etnik Murut Tahol, pengkaji telah melawat dan tinggal di daerah kecil Kemabong sebanyak dua kali. Dalam lawatan pertama, pengkaji tinggal di tempat kajian selama dua bulan (Ogos-September 2014). Banyak maklumat tentang perubatan tradisional seperti asal usul, kepercayaan, amalan dan kaedah perubatan yang berasaskan tumbuhtumbuhan etnik Murut Tahol telah dikumpulkan. Dalam lawatan kedua, pengkaji telah tinggal di tempat kajian selama satu bulan (Oktober 2015). Dalam keduadua lawatan ini, sebanyak 26 orang informan berketurunan etnik Murut Tahol telah ditemu bual. Hasil daripada temu bual tersebut, sebanyak 25 buah memorat yang berkait dengan amalan perubatan tradisional etnik Murut Tahol secara turun-temurun telah diperoleh yang mana 19 daripadanya ialah memorat yang berkait dengan perubatan rohani dan 6 buah memorat berkait dengan perubatan fizikal. Sinopsis kesemua kisah memorat yang berkait dengan perubatan rohani dan fizikal etnik Murut Tahol yang diperoleh dari tempat kajian disertakan dalam Lampiran 2 dan Lampiran 3. Memorat yang berkait dengan perubatan rohani dilabelkan dengan MR1, MR2 dan seterusnya (lihat Lampiran 2), manakala memorat yang berkait dengan perubatan fizikal dilabelkan dengan MF1, MF2 dan seterusnya (lihat Lampiran 3). 


\section{Unsur Kepercayaan dalam Memorat yang Berkait dengan Perubatan Tradisional}

Berdasarkan sinopsis kisah-kisah memorat yang dikumpulkan, perbincangan seterusnya tertumpu pada unsur kepercayaan yang terkandung dalam memoratmemorat yang berkait dengan perubatan tradisional etnik Murut Tahol. Dalam sistem kepercayaan tradisional etnik Murut Tahol, alam semesta dan seluruh isinya termasuklah bulan, bintang, matahari, manusia, haiwan, tumbuh-tumbuhan dan sebagainya telah dicipta oleh Aki Kaulung, iaitu Pencipta Murut Tahol (Abdul Hakim 2014, 425-426; Ismail 2012, 38). Kesemua ciptaan Aki Kaulung tersebut dipercayai memiliki semangat Aki Kaulung di dalamnya. Selain itu, terdapat pelbagai jenis semangat lain yang tidak dapat dilihat pada pandangan mata kasar manusia namun dipercayai turut menghuni di alam ini. Semangat-semangat tersebut dipercayai boleh mendatangkan penyakit kepada manusia (Fung 2003, 15). Sehubungan itu, Abdul Hakim $(2014,426)$ dan Ismail $(2012,38)$ dalam tulisan mereka mencatatkan bahawa etnik Murut Tahol akan sentiasa menjaga keharmonian antara dunia manusia dengan dunia ghaib bagi mengelakkan diri dan keluarga mereka ditimpa sebarang penyakit. Informan 7, Informan 9, Informan 21 dan Informan 25 memberitahu bahawa kesemua jenis semangat yang ada di alam ini mempunyai nama panggilan mereka yang tersendiri, antaranya seperti amamalir (semangat yang menyesatkan manusia), mondou (semangat harimau) dan banyak lagi.

Jika diteliti, unsur kepercayaan yang berkait dengan amalan perubatan tradisional etnik Murut Tahol secara turun-temurun turut ditemui dalam cerita memorat yang diwarisi oleh mereka. Daripada segi perubatan rohani, MR1, MR2 dan MR3 membayangkan bahawa amalan perubatan rohani etnik Murut Tahol berkait rapat dengan pandangan dunia dan kepercayaan mereka terhadap semangat ghaib secara turun-temurun. Dalam kepercayaan tradisional etnik Murut Tahol, setiap tumbuhtumbuhan yang boleh digunakan sebagai ubat-ubatan mempunyai semangat penjaganya yang tersendiri. Sehubungan itu, MR1, MR2 dan MR3 menjelaskan bahawa semangat yang tinggal di dalam tumbuh-tumbuhan yang sebenarnya membantu manusia mengubati penyakit yang mereka hidapi. Dalam sesetengah keadaan, terdapat juga semangat ghaib yang akan membantu manusia mengubati penyakit tertentu dengan cara memberitahu punca yang menyebabkan seseorang jatuh sakit. Informan 27 sebagai contoh telah mengisahkan bahawa batang luva (sejenis tumbuhan) yang telah dikeringkan digunakan oleh etnik Murut Tahol untuk mencari punca penyakit rohani. Amalan mencari punca penyakit ini dikenali sebagai antutup. Seseorang pengamal perubatan perlu memasukkan dua kerat luva yang telah dipotong ke dalam mangkuk berisi air dan melafazkan uwakin (pertanyaan kepada semangat luva) sambil mengetuk-ngetuk tepi mangkuk yang 
berisi air. Semasa amalan antutup dilakukan, seseorang pengamal perubatan haruslah memberikan kepercayaan penuh terhadap semangat yang tinggal di dalam luva tersebut untuk mendapatkan petunjuk daripadanya. Dalam hal ini, semangat di dalam luva dipercayai akan memberikan petunjuk dengan cara mencantumkan dua batang luva yang telah dimasukkan ke dalam mangkuk yang berisi air.

Etnik Murut Tahol turut mempercayai bahawa terdapat juga semangat jahat seperti alinguh (semangat yang selalunya keluar pada waktu petang) yang akan menganggu manusia. Melalui MR2 sebagai contoh, bayi yang menangis tidak henti-henti dipercayai sedang diganggu oleh semangat jahat; manakala dalam cerita MF1 pula, bahagian pusat bayi yang bengkak, berair dan berwarna kemerah-merahan dipercayai turut berpunca daripada gangguan semangat jahat, dan oleh sebab itu kaedah perubatan moden tidak dapat menyembuhkannya. Dalam kepercayaan tradisional etnik Murut Tahol, bayi dan kanak-kanak mudah mendapat gangguan makhluk halus disebabkan oleh semangat mereka yang masih lagi lemah. Dalam hal ini, Informan 4 dan Informan 7 memberitahu bahawa golongan inilah yang kerap diganggu oleh alinguh. Jika diamati, kepercayaan terhadap semangat ghaib juga ada dalam kalangan etnik peribumi yang lain. Etnik Kadazan dan Dusun sebagai contoh, mempunyai kepercayaan terhadap kewujudan pelbagai jenis semangat baik dan semangat jahat (Low dan Sri Ningsih 2013, 49-50; Low dan Azlan 2014, 80). Dalam kepercayaan tradisional etnik Kadazan dan Dusun, berbuat perkara yang tidak sopan dan menjejaskan keseimbangan antara dunia nyata dengan dunia ghaib sama ada secara sengaja ataupun tidak akan menyebabkan mereka jatuh sakit (Low dan Sri Ningsih 2013, 49-50). Dalam hal ini, etnik Murut, Kadazan dan Dusun didapati mempunyai kepercayaan yang sama, iaitu terdapat semangat di alam ghaib yang boleh menyebabkan manusia jatuh sakit.

Selain itu, rata-rata informan etnik Murut Tahol mempercayai bahawa amalan perubatan tradisional yang diamalkan ini adalah disebabkan kaedah yang digunakan oleh seseorang lumaahon (bomoh Murut Tahol) dalam memperoleh ilmu perubatan. Beberapa orang informan memberitahu bahawa ilmu perubatan yang dimiliki oleh lumaahon ataupun ulun akatohom (orang tua yang berpengetahuan dalam hal ehwal perubatan tetapi pengetahuan perubatannya adalah di bawah seorang lumaahon) diperoleh melalui pelbagai cara. Dalam kisah MR1 dan MR7 sebagai contoh, diceritakan bahawa terdapat etnik Murut Tahol yang memperoleh ilmu perubatan setelah mengambil avuk (rambut) semangat panandom (semangat yang sering menjelmakan diri sebagai perempuan cantik). MR2 pula mengisahkan seorang lumaahon yang telah memperoleh azimat perubatan berupa sejenis batu daripada mondou (semangat harimau). Sementara itu, MR3 pula mengisahkan seorang Murut Tahol yang telah memperoleh azimat perubatan berupa daun hitam daripada jelmaan seekor ular Mantakah yang ghaib secara tiba-tiba. Seterusnya, 
MR5 pula mengisahkan seorang lumaahon Murut Tahol yang telah memperoleh azimat berupa batu arang daripada buhang (semangat penjaga haiwan). Selain itu, terdapat juga ilmu perubatan yang diperoleh lumaahon dan ulun akatohom melalui jelmaan semangat tertentu serta melalui pertapaan di kubur seperti yang dikisahkan dalam MR4 dan MR6. Dalam MR4, dikisahkan bahawa tiga jenis semangat telah datang berdamping secara tiba-tiba dengan Encik Anduhut sewaktu beliau masih bergelar seorang lumaahon dan telah memberikan pengetahuan perubatan kepadanya. MR6 pula mengisahkan pengalaman seorang Murut Tahol yang telah disuruh bertapa di kubur dan air terjun. Sewaktu bertapa, beliau telah memperoleh azimat perubatan berupa batu dan digunakan untuk mengubati orang sakit dengan memandikan mereka menggunakan batu tersebut.

MR1, MR2, MR3, MR4, MR5, MR6 dan MR7 secara ringkasnya mengisahkan bagaimana seseorang pengamal perubatan Murut Tahol memperoleh pengetahuan perubatan mereka berasaskan unsur ghaib yang tertentu. Informan 1, Informan 12 dan Informan 19 memberitahu bahawa terdapat sesetengah warga tua Murut Tahol yang dipilih oleh Aki Kaulung untuk mendapat sesuatu ilmu perubatan dengan cara yang luar biasa kerana mereka ialah atulai (orang yang baik dan bertuah). Berikut adalah salah satu petikan kata-kata informan yang menunjukkan nenek moyangnya memperoleh pengetahuan perubatan dengan cara yang luar biasa berdasarkan teks verbatim yang diterjemahkan ke dalam bahasa Melayu:

Kalau itu nini (nenek) saya kasi carita dulu-dulu ... huu ... bukan alangalang bah. Kana (kena) bawa oleh angin. Kana (kena) tiup samua (semua) badan dia. Tida (tidak) lama, dia pandai suda itu pasal kasi ubat urang (orang), pasal dari mimpi juga bah ini. (Informan 1)

Dalam hal ini, Haviland $(1993,230)$ mencatatkan bahawa cerita-cerita legenda tentang perubatan yang berkait dengan pengalaman seseorang individu selalunya berupa campuran antara realisme dengan unsur luar biasa. Berdasarkan kisah MR3 sebagai contoh, si Aki Ampiong (moyang kepada informan) telah menetak seekor ular Mantakah yang muncul secara tiba-tiba di hadapannya. Setelah ditetak, darah ular tersebut telah memercik ke serata tempat dan ia juga hilang dalam sekelip mata. Hairannya, terdapat sehelai daun kering yang berwarna hitam telah muncul di tempat kejadian. Daun itulah yang seterusnya digunakan oleh si Aki Ampiong untuk mengubati orang sakit. Dalam hal ini, etnik Murut Tahol percaya bahawa hanya orang tertentu sahaja yang dapat memperoleh ilmu perubatan dengan cara luar biasa yang sedemikian.

Oleh sebab ilmu perubatan yang dimiliki oleh lumaahon dan ulun akatohom dalam kalangan etnik Murut Tahol diperoleh melalui unsur luar biasa, maka mereka 
juga mempunyai pengetahuan untuk mengubati sesuatu penyakit misteri. Dalam MR8 sebagai contoh, dikisahkan tentang seorang lelaki Murut bernama Ansulon yang sering jatuh sakit kerana namanya sama dengan nama makhluk halus, iaitu Ansulon. Hal ini menyebabkan makhluk halus tersebut berdamping dengannya dan menyebabkannya dihidapi penyakit misteri seperti badan menjadi kurus dan tidak bermaya. Hanya apabila namanya diubah menjadi Kuimin, dia telah sembuh. Selain itu, MR9 dan MR10 turut mengisahkan seorang lagi Murut Tahol yang telah jatuh sakit secara misteri. Dalam MR9, dikisahkan tentang kaki seorang pesakit Murut Tahol dalam keadaan bergulung manakala dalam MR10 pula, dikisahkan seorang Murut Tahol yang kerap jatuh pengsan secara tiba-tiba. Kedua-dua penyakit misteri ini telah diubati oleh bomoh etnik Murut Tahol. Si pesakit yang kakinya bergulung telah dimandikan dengan air yang dicampurkan dengan pelbagai jenis bunga, daun tumbuh-tumbuhan dan akar kayu sambil dibaca sasampui (jampi). Dalam hal ini, etnik Murut Tahol mempercayai bahawa penyakit misteri yang dialami oleh mereka hanya boleh diubati dengan menggunakan kaedah perubatan yang dipraktiskan oleh lumaahon sahaja. Daripada aspek lain, keupayaan seseorang lumaahon dalam menyembuhkan pelbagai jenis penyakit misteri yang dihidapi oleh pesakit Murut Tahol telah menambahkan keyakinan etnik ini terhadap ilmu perubatan tradisional yang diwarisi daripada leluhur mereka sejak turun-temurun.

Selain kaedah mendapatkan ilmu perubatan, etnik Murut Tahol juga mempercayai amalan perubatan tradisional disebabkan oleh penggunaan sasampui oleh lumaahon atau orang tua mereka. Informan 8 memberitahu bahawa seseorang lumaahon akan melafazkan pelbagai jenis sasampui semasa mengubati penyakit tertentu. Sebagai contoh, dalam MR1 dan MR2, jika seorang bayi menangis sehingga tidak dapat mengeluarkan suara, maka orang tua Murut Tahol yang arif biasanya akan melafazkan sasampui di samping menggunakan tumbuh-tumbuhan dalam mengubatinya. Sasampui yang biasa dilafazkan oleh etnik Murut Tahol ketika mengubati bayi yang diganggu oleh semangat jahat ditunjukkan dalam Jadual 1.

Jadual 1. Sasampui yang dilafazkan oleh Informan 5

\begin{tabular}{ll}
\hline Bacaan & Terjemahan \\
\hline Ikaa vaayon & Jangan menangis (disebabkan semangat) \\
Makou koh (alinguh) & Jalanlah kau (nama semangat) \\
Mulou koh antangi & Berhentilah kau menangis \\
Hino noh uvat nano & Itulah sudah ubat dia \\
\hline
\end{tabular}

Berdasarkan penelitian pengkaji, pelbagai etnik peribumi lain dan masyarakat Melayu di Sabah dan di Semenanjung Malaysia juga menggunakan mantera, jampi serapah atau doa secara meluas dalam bidang perubatan tradisional (Charles 2003, 59; Norlizawati dan Rahimah 2013, 133; Saad, Zuraidah dan Adenan 2013, 158; 
Hamidah 2013, 92). Charles $(2003,59)$ dalam kajiannya mencatatkan bahawa orang Melayu di Sabah menggunakan doa dalam amalan perubatan tradisional mereka untuk memohon bantuan daripada tuhan. Hamidah $(2013,92)$ pula mencatatkan bahawa jampi lazimnya digunakan dalam perubatan masyarakat Melayu semasa mengubati kanak-kanak yang sakit perut dan ibu yang bersalin. Dalam konteks kepercayaan terhadap penggunaan jampi bagi tujuan perubatan, sasampui yang digunakan oleh etnik Murut Tahol adalah mirip kepada doa atau jampi yang digunakan oleh masyarakat Melayu semasa mengubati seorang bayi yang sakit perut. Kepercayaan terhadap sasampui dikatakan telah berakar umbi dalam kehidupan Murut Tahol sejak turun-temurun dan membuatkan mereka percaya bahawa kaedah perubatan yang diamalkan ini adalah lebih mujarab.

Etnik Murut Tahol juga didapati menggunakan pelbagai jenis azimat dalam perubatan tradisional mereka, antaranya seperti rambut, batu, daun hitam, batu arang dan lain-lain. Menurut Arba'iyah (2014, 140), penggunaan azimat untuk tujuan perubatan adalah wajib dalam kepercayaan masyarakat tradisional. Hal ini kerana azimat atau tangkal dipercayai dapat melindungi seseorang daripada gangguan kuasa jahat sama ada semasa orang tersebut sedang melakukan proses pengubatan ataupun tidak (Charles 2003, 14). Dalam kajian Mohd Nizam (2015, 19) pula, ada dicatatkan bahawa pelbagai azimat yang digunakan oleh seseorang sebagai ilmu perubatan atau pendinding biasanya wujud dalam pelbagai bentuk dan saiz, sama ada kecil ataupun besar - contohnya seperti pingat gangsa, kuku badak sumbu, kulit ular kering, objek kristal, karang dan sebagainya. Bagi etnik Murut Tahol pula, daun hitam, batu warna hitam dan kelabu, rambut, taring babi dan benda-benda ajaib lain sering dijadikan sebagai azimat. Mereka percaya bahawa azimat-azimat seperti ini akan menjauhkan seseorang daripada gangguan saitan (semangat jahat). Hal ini turut dinyatakan oleh Charles $(2003,14)$ dan Mohd Nizam $(2015,19)$ bahawa azimat bertujuan untuk mengelakkan diri seseorang daripada diganggu kuasa jahat. Bagi etnik Murut Tahol, selain mengelakkan gangguan kuasa jahat, segala bentuk azimat yang dimiliki mereka turut digunakan untuk mengubati pelbagai jenis penyakit rohani yang dialami oleh ahli keluarga, saudara-mara atau jiran tetangga.

Penggunaan pelbagai jenis azimat yang sedemikian oleh lumaahon dalam perubatan tradisional telah menyebabkan mereka mendapat kedudukan penting dalam kalangan etnik Murut Tahol. Hal ini kerana ilmu perubatan yang dipraktiskan oleh mereka lebih diyakini dengan adanya unsur luar biasa yang digunakan bersama azimat-azimat tersebut. Beberapa orang informan turut memberitahu bahawa semakin banyak azimat atau barangan yang dimiliki oleh seseorang bomoh, maka semakin tinggi ilmunya, malah bomoh tersebut juga semakin dipandang tinggi oleh etnik Murut Tahol. Dalam hal ini, Arba'iyah $(2014,163)$ mencatatkan bahawa 
kedudukan dan status seseorang bomoh cukup berpengaruh dalam kalangan masyarakat tradisional. Bomoh dalam kalangan etnik Murut Tahol juga dilihat mempunyai pengaruh yang tersendiri dalam masyarakat mereka sejak turuntemurun. Oleh yang demikian etnik Murut Tahol sangat mempercayai kaedah perubatan tradisional yang diamalkan oleh lumaahon.

Kepercayaan terhadap amalan perubatan tradisional dalam kalangan etnik Murut Tahol juga disebabkan oleh faktor keberkesanan kaedah perubatan yang mereka amalkan. Berdasarkan hasil transkripsi temu bual dalam kerja lapangan, kesemua informan didapati meyakini amalan perubatan tradisional yang diwarisi mereka selama ini berkesan dalam mengubati penyakit rohani dan fizikal yang mereka hidapi. Berhubung hal ini, beberapa orang informan memberitahu bahawa banyak ahli keluarga dan saudara-mara mereka yang sakit telah diubati melalui kaedah perubatan tradisional sahaja.

Berdasarkan kisah yang terdapat dalam MR1, MR2, MR3, MF1, MF2, MF3 dan MF4, kesemua etnik Murut Tahol yang dihidapi penyakit diubati dengan menggunakan kaedah perubatan tradisional sahaja. Terdapat dalam kalangan mereka yang pada mulanya menerima rawatan di klinik kesihatan atau hospital, namun kaedah perubatan moden tidak dapat mengubati penyakit yang dihidapi oleh mereka. Dalam MR19 sebagai contoh, kaki seorang wanita Murut Tahol yang sakit tidak dapat dikenal pasti puncanya oleh doktor yang merawatnya. Hanya setelah diubati oleh seorang bomoh bernama Ambului, maka barulah sakit di kakinya sembuh. Sesetengah mereka sembuh secara semula jadi dengan hanya menggunakan tumbuh-tumbuhan, iaitu seperti yang dikisahkan dalam MF2. Dalam MF3 pula, diceritakan seorang lelaki Murut yang perlu dibedah dalam tempoh tiga hari disebabkan oleh penyakit batu karangnya yang sudah berada pada tahap serius. Namun, setelah minum air rebusan daun penghancur batu, sakit batu karang yang dihidapi oleh si lelaki Murut ini akhirnya sembuh secara semula jadi.

Dalam kaedah perubatan tradisional etnik Murut Tahol, sama ada perubatan yang berkait dengan penyakit rohani ataupun fizikal, mereka telah menggunakan pelbagai jenis tumbuh-tumbuhan sebagai bahan ubatnya. Dalam hal ini, etnik Murut Tahol didapati meyakini dan mempercayai kemujaraban tumbuh-tumbuhan yang berfungsi sebagai ubat-ubatan daripada nenek moyang mereka yang terdahulu tanpa mempersoalkannya. Menurut Foo $(2014,118)$, terdapat pelbagai jenis tumbuhan yang telah digunakan oleh masyarakat tradisional dalam perubatan tradisional mereka seperti tumbuhan raja kayu, akar embun, jerangau merah, mahkota dewa dan sebagainya. Yoserizal dan Jamaluddin $(2012,198)$ mencatatkan bahawa kesemua jenis tumbuhan yang boleh digunakan dalam perubatan tradisional sehingga hari ini dipercayai mengandungi khasiat tertentu yang telah dikenal pasti 
oleh nenek moyang manusia pada masa lalu. Bagi etnik Murut Tahol, pelbagai jenis tumbuhan digunakan oleh mereka untuk mengubati pelbagai penyakit rohani mahupun fizikal yang dialami oleh ahli keluarga atau saudara-mara mereka yang terdekat. Melalui kisah yang terdapat dalam MF1, MF2, MF3, MF4, MF5 dan MF6 sebagai contoh, dirakamkan bahawa luva (batang sejenis pokok - MF1), talirus (sejenis daun - MF2), pangancur vatu (daun penghancur batu - MF3), rumput tahi ayam (MF4), sejenis akar (MF5) dan daun vuyu (sirih hutan - MF6) telah digunakan oleh etnik Murut Tahol untuk mengubati bayi yang mempunyai penyakit pusat merah (MF1), gatal tubuh (MF2), batu karang (MF3), bisul (MF4), sakit pinggang (MF5) dan luka di kaki (MF6). Sehubungan itu, Foo $(2014,119)$ dalam kajiannya juga telah mencatatkan bahawa penggunaan tumbuh-tumbuhan sebagai ubat-ubatan masih kekal dalam kalangan sesetengah golongan masyarakat sehinggalah hari ini. Pengetahuan tentang penggunaan tumbuh-tumbuhan sebagai ubat-ubatan oleh etnik Murut Tahol diperoleh daripada orang tua mereka sejak dari kecil, antaranya melalui penceritaan kisah-kisah mitos dan legenda serta tunjuk ajar secara praktikal oleh golongan tua. Oleh sebab kehidupan etnik Murut Tahol sangat bergantung pada alam, terutama daripada aspek kesihatan, maka pengetahuan tentang kegunaan pelbagai jenis tumbuhan tersebut kekal dalam ingatan dan masih dipraktiskan oleh sebilangan kecil mereka sehinggalah zaman moden ini.

Berdasarkan perbincangan di atas, memorat perubatan dalam kalangan etnik Murut Tahol didapati mempengaruhi kepercayaan etnik ini terhadap amalan perubatan tradisional yang diwarisi oleh mereka secara turun-temurun daripada nenek moyang sejak dari dahulu. Hal ini kerana memorat yang dituturkan kepada mereka berdasarkan kisah benar orang tua yang telah menceritakannya. Kisah-kisah benar sedemikian telah mendorong etnik Murut Tahol untuk tetap mempercayai dan meyakini kaedah perubatan tradisional walaupun kini terdapat sistem perubatan moden yang lebih canggih; lebih-lebih lagi ia terbukti berdasarkan pengalaman perubatan sebenar ahli keluarga ataupun saudara-mara mereka sendiri. Perbincangan seterusnya menumpukan kepada unsur kearifan tempatan yang terkandung dalam kesemua kisah memorat yang berkait dengan perubatan rohani dan memorat yang berkait dengan perubatan fizikal etnik Murut Tahol dalam kajian ini.

\section{Unsur Kearifan Tempatan}

Patthira $(2013,6)$ mencatatkan bahawa kearifan tempatan yang dimiliki oleh pengamal perubatan merupakan kearifan tradisional yang menggunakan kefahaman kesihatan terhadap tubuh badan seseorang, minda dan masyarakat. Norlizawati dan Rahimah $(2013,131)$ pula menjelaskan bahawa kearifan jenis ini lebih menjurus kepada amalan perubatan tradisional yang menggunakan sumber alam sebagai 
ubat-ubatan yang diwarisi sejak dari dahulu sehingga ke hari ini dalam kalangan sesebuah masyarakat. Dalam hal ini, Informan 1, Informan 3 dan Informan 15 memberitahu bahawa ilmu pengetahuan yang berkait dengan perubatan tradisional telah diwarisi oleh mereka daripada satu generasi kepada satu generasi lain sehingga ke hari ini. Ternyata penyebaran unsur kearifan tempatan dalam kalangan etnik Murut Tahol telah pun berlaku sejak sekian lama.

Etnik Murut Tahol secara turun-temurun telah mempunyai pengetahuan khusus tentang hutan-hutan yang mempunyai banyak tumbuhan yang boleh digunakan sebagai ubat-ubatan. Hal ini kerana mereka telah lama tinggal di kawasan belantara dan berbukit-bukau, dan mereka telah lama mengenali jenis-jenis hutan di kawasan berdekatan tempat tinggal mereka. Pengetahuan khusus ini diperoleh secara turuntemurun daripada satu generasi kepada generasi yang lain. Mereka mempunyai kearifan tentang lokasi hutan yang ditumbuhi pokok-pokok besar dan tumbuhan yang sesuai dijadikan ubat-ubatan, serta mereka juga mengetahui kawasan yang terdapat pokok-pokok kecil serta tumbuhan renek dan herba. Pengetahuan ini diperoleh melalui ajaran orang terdahulu dan kepekaan mereka terhadap jenis tumbuh-tumbuhan yang ada di alam sekitar. Oleh yang demikian, apabila terdapat dalam kalangan anggota keluarga ataupun saudara-mara mereka yang sakit, mereka sudah sedia mengetahui kawasan yang sesuai untuk mendapatkan ubat-ubatan. Informan 3, Informan 11 dan Informan 17 memberitahu bahawa pengetahuan khusus sedemikian yang telah diwarisi sejak kecil lagi memudahkan mereka membuat keputusan dengan cepat dan bertindak segera jika ada dalam kalangan ahli keluarga mereka yang tiba-tiba jatuh sakit.

Berdasarkan kisah-kisah memorat daripada lapangan pula, warga tua etnik Murut Tahol secara turun-temurun didapati bijak mengenal pasti ciri-ciri yang ada pada tumbuh-tumbuhan yang boleh digunakan sebagai ubat-ubatan. Mereka dapat membezakan jenis-jenis daun, akar, batang dan kulit pada tumbuh-tumbuhan yang boleh digunakan sebagai ubat-ubatan. Bentuk, warna, bau dan rasa yang ada pada bahagian pelbagai tumbuh-tumbuhan turut dijadikan panduan. Mereka juga dapat mengenal pasti jenis tumbuh-tumbuhan yang dapat digunakan sebagai ubat-ubatan dengan meneliti secara terperinci bahagian permukaan tumbuh-tumbuhan tersebut. Antaranya adalah seperti perbezaan permukaan tumbuhan sama ada daun, akar, batang, pucuk, buah ataupun akarnya seperti kesan tompokan, permukaan kasar dan lembut yang dapat dirasa dengan sentuhan tapak tangan. Hal ini membolehkan mereka mengenal pasti jenis tumbuhan yang boleh digunakan sebagai ubat-ubatan. Selain melalui teknik sentuhan, etnik Murut Tahol juga dapat mengenali tumbuhtumbuhan jenis ubat dengan cara mengesan rasa cecair yang ada pada kulit tumbuhan tersebut dan dapat membezakan jenis-jenis kepahitannya. Pengetahuan turun-temurun yang sedemikian telah mempengaruhi kepekaan dan tindak balas 
etnik Murut Tahol semasa berlakunya sebarang kejadian yang tidak diingini. Melalui kisah MF4 contohnya, apabila kaki lelaki Murut luka secara tidak sengaja semasa membersihkan kawasan hutan, isterinya akan bertindak dengan memetik daun vиyu (sirih hutan), melumatkannya dan menyapunya di atas permukaan luka suaminya. Perbuatan ini menunjukkan bahawa etnik Murut Tahol memiliki kearifan untuk memilih jenis tumbuhan yang boleh digunakan sebagai ubat ketika berlakunya kecemasan. Si isteri dalam memorat ini didapati arif tentang penggunaan vuyu untuk menghentikan darah yang keluar daripada luka sejak kecil lagi.

Selain itu, etnik Murut Tahol juga mempunyai kearifan daripada segi kaedah penyediaan tumbuh-tumbuhan sebagai ubat-ubatan untuk mengubati pelbagai jenis penyakit rohani dan fizikal. Informan 4, Informan 10 dan Informan 14 memberitahu bahawa antara kaedah penyediaan ubat-ubatan yang diwarisi daripada orang tua mereka terdahulu adalah seperti merebus, membakar, memasak, menumbuk, menjemur, melumat, memerah dan sebagainya. Kaedah penyediaan ubat-ubatan sedemikian turut terdapat dalam kisah memorat mereka, iaitu seperti yang dikisahkan dalam MF4. Dalam memorat ini, si Pilaus mengubati sakit bisul di kakinya dengan cara melumatkan daun luluyas (rumput tahi ayam) pada tapak tangannya dan ditampal pada permukaan bisul. Jika diamati, etnik Murut Tahol mempunyai pengetahuan yang khusus dalam melumatkan daun luluyas, iaitu dengan memastikan daunnya tidak terputus dan cecair yang terdapat pada permukaannya adalah mencukupi. Daun luluyas yang telah dilumatkan akan dilekatkan pada permukaan bisul dan dibiarkan selama beberapa saat sebelum ditarik daripada permukaan bisul tersebut dengan pantas. Sewaktu daun luluyas tersebut ditarik, nanah pada bisul yang melekat pada permukaan daun tersebut akan ditarik keluar. Informan 1 dan Informan 26 memberitahu bahawa jika daun luluyas dilumatkan sehingga terputus atau terlebih lendir pada permukaannya, daun tersebut tidak boleh digunakan lagi. Kesemua teknik perubatan untuk merawat bisul merupakan kearifan khusus yang ada pada seseorang pengamal perubatan tradisional etnik Murut Tahol.

Berdasarkan penelitian pengkaji, etnik peribumi lain turut mempunyai kaedah penyediaan ubat-ubatan mereka yang tersendiri. Orang Melayu sebagai contoh, menyediakan ramuan ubat-ubatan daripada tumbuh-tumbuhan dengan cara merebus, mencelur, menyalai, menumbuk, melumat, mengering, meramas, membakar dan merendam tumbuh-tumbuhan tersebut sebelum digunakan untuk mengubati sesuatu penyakit tertentu (Fatan Hamamah 2003, 4). Seperti etnik Murut Tahol, orang Melayu juga mempunyai kaedah penyediaan ubat-ubatan daripada tumbuh-tumbuhan dengan cara melumatkannya. Daun sirih sebagai contoh, boleh dilumatkan dan dipanaskan pada api, lalu diletakkan pada perut 
bayi untuk membuang angin atau menyembuhkan kembung perut (Hamidah 2013, 92). Dalam hal ini, kaedah penyediaan ubat-ubatan daripada tumbuh-tumbuhan dengan cara melumatkannya yang dilakukan oleh etnik Murut Tahol didapati agak berbeza sedikit dengan cara orang Melayu. Hal ini kerana etnik Murut Tahol perlu memastikan bahawa tumbuhan yang dilumatkan telah berada pada tahap tertentu sebelum dapat digunakan berbanding orang Melayu yang tidak memerlukan tahap sedemikian.

Daripada aspek lain, orang tua etnik Murut Tahol didapati arif dan mempunyai pengetahuan tersendiri dalam memahami dan mentafsirkan maksud sasampui. Oleh sebab bahasa yang digunakan dalam sasampui ialah bahasa lama yang jarang digunakan pada masa ini, maka hanya lumahon (bomoh), ulun akatohom (orang tua yang mempunyai azimat) dan orang tua yang berpengetahuan sahaja yang dapat mentafsirkan maksud sasampui serta menggunakannya secara berkesan dalam perubatan tradisional mereka. Sasampui yang dibekalkan oleh Informan 6 ini hanya boleh difahami maksudnya oleh orang tertentu sahaja:

\author{
Ariuu ... Kuru-kuh \\ Rampoi vatang kamanis \\ Uliang kamanisi \\ Tuuh ... Samila
}

Informan 6 memaklumkan bahawa setiap perkataan yang digunakan dalam sasampui tersebut tidak dapat diterjemahkan ke dalam bahasa Melayu kerana bahasa yang digunakan ialah bahasa Murut Tahol lama. Oleh yang demikian, hanya orang tua Murut Tahol yang masih mewarisinya sehingga hari ini sahaja yang mengetahui maksud dan tujuan sasampui tersebut. Secara kasar, sasampui berkenaan sebenarnya bertujuan untuk memohon izin dan meminta bantuan daripada semangat penjaga tumbuh-tumbuhan di dalam hutan sebelum mereka mengambil sebarang tumbuh-tumbuhan untuk dijadikan sebagai ubat. Penggunaan sasampui dalam amalan perubatan tradisional etnik Murut Tahol secara turuntemurun telah menambahkan keyakinan etnik ini terhadap kaedah perubatan rohani dan fizikal yang dimiliki oleh mereka.

Pengalaman turut mempengaruhi unsur kebijaksanaan yang dimiliki oleh etnik Murut Tahol. Menurut Informan 2, tumbuh-tumbuhan yang digunakan sebagai ubat-ubatan oleh etnik Murut Tahol pada hari ini sebenarnya telah dicuba dan dipraktiskan oleh nenek moyang mereka sejak berabad lamanya sebelum ia diakui sebagai ubat-ubatan. Dalam hal ini, pelbagai jenis tumbuhan telah digunakan dan dicuba secara berulang-ulang kali dalam mengubati pelbagai jenis penyakit yang dihidapi oleh etnik Murut. Apabila tumbuh-tumbuhan yang digunakan sebagai 
ubat-ubatan memberikan kesan yang baik dan menyembuhkan pesakit, maka ia akan kekal digunakan sebagai ubat. Walau bagaimanapun, sepanjang proses percubaan ini, beberapa orang informan memberitahu bahawa banyak juga nyawa (etnik Murut Tahol) yang terkorban kerana tumbuhan yang digunakan sebagai ubat ialah awanit (beracun) dan tidak mendatangkan kesan positif terhadap sesetengah penyakit. Berdasarkan percubaan dan risiko sedemikian, mereka dapat mengetahui jenis tumbuhan yang sesuai/berguna dan tidak sesuai/berguna untuk dijadikan sebagai ubat-ubatan. Oleh yang demikian, pengetahuan yang dimiliki oleh etnik Murut Tahol pada masa ini diwarisi daripada pengalaman sebenar nenek moyang mereka pada zaman dahulu. Ringkasnya, kearifan yang berkait dengan perubatan tradisional dalam kalangan etnik Murut Tahol sejak sekian lama ini telah banyak membantu meringankan beban hidup mereka daripada aspek kesihatan.

Jika diteliti, unsur-unsur kearifan tempatan ini mempunyai kaitan yang rapat dengan kepercayaan etnik Murut Tahol. Daripada segi pengetahuan khusus tentang tempat terdapatnya tumbuh-tumbuhan berubat, etnik Murut Tahol percaya bahawa tempat-tempat tersebut dihuni oleh pelbagai jenis semangat hutan. Tempat-tempat yang dihuni oleh semangat hutan mempunyai tanda-tanda khusus seperti adanya busut dan pohon yang luar biasa besar di hutan. Tempat-tempat inilah yang dijadikan panduan oleh etnik Murut Tahol untuk mencari tumbuh-tumbuhan yang boleh dijadikan ubat. Ternyata kepercayaan etnik Murut Tahol terhadap pelbagai semangat di sekeliling mereka telah mempengaruhi kearifan mereka daripada segi pencarian tumbuh-tumbuhan yang sesuai dijadikan ubat. Hal ini telah disahkan oleh Informan 1 dan Informan 2 bahawa etnik Murut Tahol dahulu telah bergantung pada kepercayaan sedemikian untuk mencari tumbuhan berubat di hutan.

Daripada segi kaedah penyediaan ubat-ubatan, terdapat juga kaitan antara kearifan tempatan dengan unsur kepercayaan turun-temurun etnik Murut Tahol. Berdasarkan pemerhatian dalam kerja lapangan, beberapa orang informan didapati melafazkan sesuatu ketika mereka menyediakan ubat-ubatan sama ada dengan cara menumbuk, memerah ataupun merebus tumbuh-tumbuhan. Yang dilafazkan oleh mereka ialah kata-kata biasa dan bukannya sasampui. Perbuatan sedemikian merupakan kepercayaan pengamal perubatan bahawa dengan berbuat demikian ubat-ubatan yang disediakan oleh mereka itu akan menjadi lebih mujarab.

Satu lagi kaitan antara kearifan tempatan dengan unsur kepercayaan ialah penggunaan sasampui dalam perubatan rohani. Sebagai contoh, ketika seseorang terkena buatan orang, pengamal perubatan akan melafazkan sasampui atas sebotol air dan kemudian meludah ke arah air tersebut. Air yang dilafazkan sasampui itu dijadikan penawar bagi orang yang terkena buatan orang. Kaedah perubatan rohani sedemikian adalah mudah namun didapati kearifan tempatan dan kepercayaan 
etnik Murut Tahol telah dicampuradukkan. Selain perubatan rohani, sasampui juga digunakan dalam sesetengah pengubatan fizikal. Dalam kes orang yang menghidap penyakit batu karang, pesakit akan dimandikan dengan air yang sudah dibaca sasampui dengan pinggangnya dililit dengan sejenis akar kayu. Dalam kaedah perubatan ini, pesakit juga diberi air yang telah dibaca sasampui seperti kes pesakit yang terkena buatan orang. Penggabungan antara penggunaan sasampui dengan kaedah perubatan tradisional bukan sahaja terhad kepada kedua-dua kes di atas, malah terdapat juga kes-kes lain yang tidak dilaporkan dalam makalah ini. Yang jelas, gabungan sasampui dengan kaedah perubatan tradisional seperti ini menonjolkan kaitan antara kearifan tempatan dengan kepercayaan etnik Murut Tahol secara turun-temurun.

\section{Kesimpulan}

Secarakeseluruhannya, kisah-kisah memoratsememangnnya sangat mempengaruhi kepercayaan etnik Murut Tahol terhadap amalan perubatan tradisional yang telah diwarisi oleh mereka secara turun-temurun. Berdasarkan kisah memorat yang telah dibincangkan, etnik Murut Tahol didapati mempunyai kepercayaan terhadap semangat baik dan jahat yang mempengaruhi kesihatan mereka. Semangat baik dipercayai membantu mereka mengubati penyakit dengan memberikan petuapetua tertentu, manakala semangat jahat pula akan menyebabkan manusia jatuh sakit jika mereka diganggu. Selain itu, etnik Murut Tahol juga mempercayai sasampui yang digunakan oleh tukang ubat yang kebanyakannya terdiri daripada orang tua Murut Tahol. Selain itu, keberkesanan kaedah perubatan tradisional yang diwarisi oleh pewaris etnik Murut Tahol yang tertentu juga menyebabkan mereka mempercayai amalan perubatan yang dipraktiskan sehingga ke hari ini.

Daripada segi kearifan tempatan, kearifan yang dimiliki mereka berkait rapat dengan faktor-faktor seperti pengetahuan perihal ciri-ciri yang ada pada tumbuhtumbuhan yang digunakan sebagai ubat-ubatan, kemahiran dalam kaedah penyediaan ubat-ubatan daripada tumbuh-tumbuhan serta kebolehan mentafsir maksud sasampui yang digunakan untuk tujuan perubatan. Kearifan perubatan tradisional yang sedemikian telah diwarisi secara turun-temurun daripada nenek moyang etnik Murut Tahol dan masih dimiliki sehingga ke hari ini. 


\section{Penghargaan}

Penulis ingin merakamkan ribuan terima kasih kepada Kementerian Pengajian Tinggi yang memperuntukkan Geran LRGS/TD/2012/USM-UKM/KT/03 untuk menampung perbelanjaan yang digunakan dalam menjalankan kerja lapangan di daerah kecil Kemabong, Sabah. Setinggi-tinggi terima kasih juga diucapkan kepada Dr. Hasmidar Hassan, Universiti Malaya yang telah membetulkan aspek bahasa Melayu dalam makalah ini.

\section{Nota}

1. Terdapat sebanyak 12 etnik Murut yang berlainan di Sabah, antaranya ialah etnik Tahol (Tagal) atau Sumambu, Timugon, Paluan, Bookan (dahulu dikenali sebagai Baukan), Gana, Murut Keningau, Murut Beaufort, Murut Kalabakan, Okolod (juga disebut sebagai Kolod), Murut Selungai atau Salungai, Murut Sembakung atau Sambakung dan Murut Serudung atau Sarudung (Pugh-Kitingan 2012, 25). Pada asalnya, istilah 'Murut' digunakan oleh beberapa orang pengkaji untuk merujuk kepada penduduk peribumi yang tinggal di pedalaman Kalimantan, Sabah dan Sarawak (Ismail 2007, 59; Pugh-Kitingan 2012, 25). Seterusnya, Fung $(2003,15)$ dan beberapa orang pengkaji lain menjelaskan bahawa istilah Murut membawa maksud orang bukit (hill people). Hal ini disebabkan oleh kawasan petempatan mereka yang tertumpu di kawasan pedalaman yang berbukit. 


\section{Lampiran 1}

\section{Catatan:}

1. Nama sebenar informan dirahsiakan dan digantikan dengan Informan 1, Informan 2, Informan 3 dan seterusnya.

2. Susunan informan bermula dengan usia informan yang paling tua kepada informan yang paling muda.

3. Selain umur, jantina dan pekerjaan, maklumat peribadi lain yang boleh mendedahkan identiti informan tidak disenaraikan dalam jadual.

\begin{tabular}{|c|c|c|c|c|}
\hline Bil. & Nama Informan & Umur & Jantina & Pekerjaan \\
\hline 1. & Informan 1 & 97 & Lelaki & Petani \\
\hline 2. & Informan 2 & 83 & Lelaki & Petani \\
\hline 3. & Informan 3 & 82 & Perempuan & Petani \\
\hline 4. & Informan 4 & 80 & Perempuan & Petani \\
\hline 5. & Informan 5 & 80 & Lelaki & Petani \\
\hline 6. & Informan 6 & 77 & Lelaki & Petani \\
\hline 7. & Informan 7 & 71 & Lelaki & Petani \\
\hline 8. & Informan 8 & 69 & Perempuan & Petani \\
\hline 9. & Informan 9 & 68 & Lelaki & Petani \\
\hline 10. & Informan 10 & 64 & Perempuan & Petani \\
\hline 11. & Informan 11 & 62 & Perempuan & Suri rumah \\
\hline 12. & Informan 12 & 61 & Lelaki & Petani \\
\hline 13. & Informan 13 & 57 & Perempuan & Suri rumah \\
\hline 14. & Informan 14 & 57 & Lelaki & Petani \\
\hline 15. & Informan 15 & 57 & Perempuan & Petani \\
\hline 16. & Informan 16 & 56 & Perempuan & Petani \\
\hline 17. & Informan 17 & 56 & Lelaki & Petani \\
\hline 18. & Informan 18 & 55 & Lelaki & Petani \\
\hline 19. & Informan 19 & 55 & Perempuan & Petani \\
\hline 20. & Informan 20 & 55 & Lelaki & Petani \\
\hline 21. & Informan 21 & 54 & Lelaki & Petani \\
\hline 22. & Informan 22 & 54 & Lelaki & Ketua Kampung \\
\hline 23. & Informan 23 & 51 & Perempuan & Petani \\
\hline 24. & Informan 24 & 51 & Perempuan & Petani \\
\hline 25. & Informan 25 & 46 & Perempuan & Petani \\
\hline 26. & Informan 26 & 40 & Lelaki & Petani \\
\hline 27. & Informan 27 & 62 & Lelaki & Petani \\
\hline
\end{tabular}




\section{Lampiran 2}

\section{Memorat yang berkait dengan perubatan rohani etnik Murut Tahol}

\begin{tabular}{|c|c|c|}
\hline Bil. & Memorat & Ringkasan cerita \\
\hline 1. & MR1 & $\begin{array}{l}\text { Seorang lelaki Murut bernama Angkaras telah terjumpa dengan seorang } \\
\text { perempuan cantik yang dipercayainya semangat panandom (sejenis hantu } \\
\text { air) lalu memotong rambutnya. Sejak itu, si Angkaras menyimpan rambut } \\
\text { panandom tersebut sebagai salah satu azimat yang digunakannya untuk } \\
\text { mengubati penyakit rohani seperti terkena teguran dan dibuat orang dalam } \\
\text { kalangan ahli keluarga atau kawan-kawannya. }\end{array}$ \\
\hline 2. & MR2 & $\begin{array}{l}\text { Terdapat seorang bomoh bernama Murut Andimau telah memperoleh } \\
\text { sejenis batu azimat daripada mondou (semangat harimau) dan pengetahuan } \\
\text { mengubati orang sakit. Sejak hari itu, si Andimau pun mahir mengubati } \\
\text { orang sakit yang disebabkan oleh perbuatan syaitan atau semangat- } \\
\text { semangat halus lain dengan menggunakan batu azimat tersebut. }\end{array}$ \\
\hline 3. & MR3 & $\begin{array}{l}\text { Dikisahkan bahawa si aki (datuk) Ampiong telah memperoleh azimat } \\
\text { berupa sehelai daun hitam yang kering daripada seekor ular Mantakah } \\
\text { yang ghaib semasa hayatnya. Sejak hari itu, daun hitam tersebut telah } \\
\text { digunakan oleh si aki Ampiong sebagai azimat untuk menyembuhkan } \\
\text { orang Murut yang sakit. Setelah pemergian si aki Ampiong, azimat tersebut } \\
\text { telah diwariskan kepada salah seorang cucunya. }\end{array}$ \\
\hline 4. & MR4 & $\begin{array}{l}\text { Memorat ini mengisahkan pengalaman Encik Anduhut sebagai seorang } \\
\text { bomoh. Pada mulanya, roh arwah bapanya telah datang berbicara dengan } \\
\text { Encik Anduhut lalu masuk ke dalam tubuhnya dan menyebabkan beliau } \\
\text { menjadi seorang bomoh. Sepanjang beliau menjadi bomoh, banyak jenis } \\
\text { semangat atau roh yang datang berdampingan dengannya termasuklah roh } \\
\text { penganut Islam. Namun roh Islam tersebut telah meninggalkannya setelah } \\
\text { dia termakan ikan bakar yang telah dibakar dengan menggunakan lemak } \\
\text { babi. Roh bapa Encik Anduhut memberitahunya bahawa kesemua semangat } \\
\text { Islam itu berasal dari langit manakala roh bukan Islam seperti bapanya } \\
\text { pula datang dari tempat tinggal yang lain. Roh bapa Encik Anduhut juga } \\
\text { memberitahunya bahawa semua benda yang hidup di dunia, termasuklah } \\
\text { tumbuh-tumbuhan mempunyai semangat penjaganya yang tersendiri. Oleh } \\
\text { itu, manusia perlu meminta kebenaran daripada semangat tersebut sebelum } \\
\text { mengambil sesuatu tumbuh-tumbuhan. Jika tidak, mereka akan dihidapi } \\
\text { penyakit. Hal ini menyebabkan orang tua Murut Tahol pada zaman dahulu } \\
\text { mengendalikan upacara ahamol (memberikan sajian kepada semangat di } \\
\text { hutan) sebelum mereka memulakan apa-apa pekerjaan di hutan. }\end{array}$ \\
\hline
\end{tabular}




\begin{tabular}{|c|c|c|}
\hline Bil. & Memorat & Ringkasan cerita \\
\hline 5. & MR5 & $\begin{array}{l}\text { Memorat ini mengisahkan si Ambului yang telah memperoleh ilmu } \\
\text { mengubati orang sakit daripada buhang (semangat penjaga haiwan). } \\
\text { Buhang ialah semangat yang akan turun ketika hari hujan. Dipercayai } \\
\text { bahawa semasa buhang turun ke bumi, jika matanya memandang ke arah } \\
\text { kayu, kayu itu akan patah. Jika matanya memandang ke arah rumah, rumah } \\
\text { tersebut akan musnah. Jika manusia yang dipandangnya, maka orang itu } \\
\text { akan mati. Pada suatu hari, ketika buhang sedang turun ke bumi, sepohon } \\
\text { pokok tinggi telah disabung kilat. Si Ambului pun memanjat sehingga } \\
\text { puncak pokok itu dan menjumpai seketul batu arang. Dipercayai bahawa } \\
\text { batu arang tersebut hanya boleh diambil dan dipegang oleh orang yang } \\
\text { terpilih sahaja. Sejak hari itu, si Ambului pun menggunakannya untuk } \\
\text { mengubati orang yang terkena teguran atau buatan orang. }\end{array}$ \\
\hline 6. & MR6 & $\begin{array}{l}\text { Terdapat seorang lelaki Murut yang telah memperoleh azimat daripada } \\
\text { tanah perkuburan. Lelaki Murut tersebut telah bermimpi berjumpa dengan } \\
\text { roh seorang bomoh yang telah menyuruhnya agar pergi ke alahalah } \\
\text { (kawasan tanah perkuburan orang Murut) untuk mengambil sesuatu. Maka, } \\
\text { dia pun pergi bertapa di kubur bomoh yang dijumpai dalam mimpinya } \\
\text { itu. Setelah beberapa minit bertapa, si lelaki Murut tiba-tiba ternampak } \\
\text { roh bomoh yang muncul daripada kuburnya dan menghulurkan sejenis } \\
\text { 'barang' kepadanya. Sebelum menghilangkan diri, roh bomoh tersebut } \\
\text { telah berpesan kepadanya agar pergi ke Bosoi Simporon (nama sebuah } \\
\text { air terjun Simporon di Kemabong) dan naik ke tingkat tiga bosoi tersebut. } \\
\text { Maka, dia pun pergilah ke situ. Dari Gua Bosoi Simporon, si lelaki Murut } \\
\text { ini terjumpa dengan mondou (semangat harimau) dan mengambil seketul } \\
\text { batu ajaib daripada mulut mondou tersebut. Batu ajaib ini seterusnya telah } \\
\text { digunakannya sebagai azimat untuk mempertahankan diri serta mengubati } \\
\text { orang yang sakit. }\end{array}$ \\
\hline 7. & MR7 & $\begin{array}{l}\text { Seorang lelaki bernama Angkuvau telah terserempak dengan dua orang } \\
\text { perempuan cantik di Sungai Padas. Seorang daripada mereka ingin } \\
\text { berkahwin dengan si Angkuvau. Si Angkuvau diberi masa selama tujuh } \\
\text { hari untuk mempertimbangkan pelawaannya. Sebelum menghilangkan } \\
\text { diri, mereka berpesan pada si Angkuvau bahawa jika dia bersetuju untuk } \\
\text { berkahwin, dia boleh datang ke Sungai Padas pada hari yang ketujuh } \\
\text { dan dia tidak akan kembali ke dunia manusia lagi kerana bakal isterinya } \\
\text { ialah panandom (semangat yang menjelmakan diri sebagai perempuan } \\
\text { cantik). Sebelum menghilangkan diri, kedua-dua panandom tersebut } \\
\text { menghadiahkan si Angkuvau sehelai rambut untuk melindunginya daripada } \\
\text { jatuh sakit serta membantunya mengubati penyakit akibat keteguran. } \\
\text { Si Angkuvau menangis-nangis dan enggan menerima pelawaan untuk } \\
\text { berkahwin dengan salah satu panandom dan dia akhirnya memutuskan } \\
\text { untuk tidak turun ke Sungai Padas menangkap ikan lagi. }\end{array}$ \\
\hline
\end{tabular}




\begin{tabular}{|c|c|c|}
\hline Bil. & Memorat & Ringkasan cerita \\
\hline 8. & MR8 & $\begin{array}{l}\text { Memorat ini mengisahkan si Kuimin yang kerap jatuh sakit disebabkan } \\
\text { oleh nama asalnya ialah Ansulon. Sejak kecil, tubuhnya kurus dan tidak } \\
\text { bermaya. Dia selalu dibawa ke rumah sakit di Keningau, namun doktor } \\
\text { gagal mengubati penyakitnya. Pada suatu malam, neneknya yang bernama } \\
\text { Limpi telah bermimpi berjumpa dengan seorang lelaki bernama Kaulung } \\
\text { dan lelaki tersebut memberitahunya bahawa si Kuimin kerap sakit kerana } \\
\text { namanya, iaitu si Ansulon yang sama maksudnya dengan ansulon (semangat } \\
\text { jahat). Kaulung juga telah berpesan pada Limpi agar menukarkan nama } \\
\text { Ansulon kepada Kuimin. Kemudian, badan si Kuimin perlu diasap dengan } \\
\text { membakar daun pamamavas ra inupi (senduduk hutan) selama empat hari. } \\
\text { Sejak hari itu, Kuimin pun tidak kerap jatuh sakit lagi sehingga ke hari ini. }\end{array}$ \\
\hline 9. & MR9 & $\begin{array}{l}\text { Salah seorang anak si Indim telah menghidapi sejenis penyakit ganjil. } \\
\text { Penyakit ini menyebabkan dia menderita selama tiga bulan kerana kakinya } \\
\text { bergulung dan tangannya pula melekat di badan. Oleh itu, anaknya tidak } \\
\text { dapat makan dengan sendiri. Si Indim pun membawa anaknya ke Kampung } \\
\text { Patian berjumpa dengan seorang bomoh yang bernama Suman. Suman } \\
\text { melafazkan sasampui dan selepas itu meniup ke arah sebotol air. Air di } \\
\text { dalam botol itu diberikan kepada anak si Indim untuk diminum setiap hari. } \\
\text { Selain itu, Suman juga memandikan anak si Indim dengan menggunakan } \\
\text { sejenis batu dan mengelap kaki dan tangannya menggunakan daun tawawo } \\
\text { pada setiap kali mengubatinya. Lama-kelamaan, kaki dan tangan anak si } \\
\text { Indim pun semakin pulih. }\end{array}$ \\
\hline 10. & MR10 & $\begin{array}{l}\text { Seorang perempuan telah jatuh sakit secara tiba-tiba. Pada mulanya, dia } \\
\text { seorang yang sihat, namun pada suatu hari, tiba-tiba dia terjatuh dan } \\
\text { matanya menjadi sindol-sindol (naik ke atas). Badannya pula menjadi } \\
\text { sejuk dan mengigil-gigil. Puas ahli keluarganya membawa dia ke banyak } \\
\text { tempat untuk berubat seperti di Sapulut, Nabawan dan Pinangoh namun } \\
\text { tiada bomoh yang dapat mengubatinya. Mereka juga membawanya ke } \\
\text { rumah sakit namun doktor tidak berjaya mengesan punca penyakitnya. } \\
\text { Akhirnya, atas cadangan daripada ahli keluarga yang lain, maka dia pun } \\
\text { dibawa berjumpa dengan seorang bomoh lelaki. Bomoh (namanya tidak } \\
\text { mahu disebut oleh informan) ini hanya memandikan si pesakit. Pesakit ini } \\
\text { pun sembuh seperti biasa. }\end{array}$ \\
\hline
\end{tabular}




\begin{tabular}{lll}
\hline Bil. & Memorat & Ringkasan cerita \\
\hline 11. & MR11 & Seorang lelaki telah jatuh sakit secara tiba-tiba dan menyebabkan dia \\
& kerap pengsan. Dia telah dibawa ke hospital Tenom, namun doktor yang \\
& merawatnya tidak dapat mengesan jenis penyakit yang dihidapinya. \\
& Ubat-ubatan yang diberikan oleh doktor juga tidak dapat menyembuhkan \\
& penyakit ganjilnya itu. Maka, ahli keluarganya pun membawa lelaki itu \\
& untuk berjumpa dengan seorang bomoh yang tinggal di seberang Sungai \\
& Padas. Sebelum mengubatinya, bomoh tersebut telah meminta dua pasang \\
& sarung dan dua ekor ayam jantan puth sebagai upah. Setelah itu, bomoh \\
& tersebut pun mengubati si lelaki itu dengan memandikannya menggunakan \\
& batu pegangan (azimat). Pelbagai jenis bunga serta tumbuhan kuruput \\
& telah dicampurkan dengan air mandian tersebut. Tumbuhan kuruput ialah \\
& bahan penting dalam air mandian kerana tumbuhan ini dipercayai dapat \\
& menyembuhkan penyakit si lelaki yang sering pengsan secara tiba-tiba. \\
& Setelah dimandikan sebanyak empat kali, penyakit ganjilnya telah sembuh \\
& sehinggalah sekarang.
\end{tabular}

12. MR12 Dikisahkan tentang seorang wanita yang telah menghidapi penyakit kudis secara tiba-tiba. Oleh sebab tempat tinggalnya jauh, dia tidak dapat pergi berjumpa dengan doktor di hospital Tenom. Oleh itu, si pesakit ini telah meminta bantuan daripada seorang bomoh, iaitu si aki Andimau. Semasa berjumpa dengan si aki Andimau, si pesakit dimandikan dengan batu azimatnya. Semasa diubati, tiga jenis benda ganjil yang berbentuk seakan-akan buah hutan telah dikeluarkan daripada kaki si pesakit. Si aki Andimau memberitahunya bahawa penyakitnya berpunca daripada si pesakit tersentuh barang-barang yang tidak baik. Setelah diubati, wanita itu tidak dibenarkan makan makanan berwarna hijau (seperti pucuk ubi, pakis dan timun), menyisip di bawah tempat menjemur kain, menyisip di bawah kolong rumah serta melangkahi tutu (kayu penumbuk padi) dan tutuan (tempat menumbuk padi) selama empat hari. Setelah si pesakit menurut semua pantang larang yang disebut oleh si aki Andimau, kudis di kakinya telah sembuh sepenuhnya.

13. MR13 Kisah ini bermula dengan seorang wanita yang telah dihidapi penyakit ganjil angkara buatan orang. Pada suatu hari, dia jatuh sakit secara tibatiba dan hampir rebah ke permukaan lantai. Setiap kali penyakitnya datang, wanita tersebut akan merasakan kepanasan dan kesejukan pada tubuhnya. Walaupun telah berkali-kali si pesakit pergi ke hospital Tenom, namun doktor tidak dapat mengesan punca penyakit ganjil yang dihidapinya. Oleh itu, ahli keluarganya pun membawa ibu mereka berjumpa dengan seorang bomoh kampung. Setelah diperiksa oleh bomoh yang berasal dari Tinangoh, dia memberitahu mereka bahawa ibu mereka telah terkena buatan seorang lelaki yang cemburu dan kecil hati terhadap mereka. Si bomoh telah menunjukkan wajah lelaki tersebut melalui mangkuk air kepada mereka. Setelah mengetahui punca penyakitnya, maka si bomoh pun memandikan wanita itu dengan menggunakan batu azimatnya. Akhir sekali, penyakit ganjil wanita itu telah sembuh sepenuhnya. 


\begin{tabular}{lll}
\hline Bil. & Memorat & Ringkasan cerita \\
\hline 14. & MR14 & Pada suatu petang, si Majina dan abangnya si Iun telah pergi mencari buah \\
& nanas di tempat ibu bapa mereka menoreh getah. Sewaktu sedang memetik \\
& buah nanas, mereka melangkahi banyak pohon nanas. Setelah hasilnya \\
& mencukupi, mereka pun kembali ke rumah. Pada waktu petang, kaki si \\
& Majina tiba-tiba berasa sakit dan sukar digerakkan seperti biasa. Si Majina \\
& pun memberitahu ibunya lalu ibunya mengendalikan amalan antutup \\
& (amalan untuk mencari punca penyakit dengan mengetuk mangkuk yang \\
& berisi air dengan dua kerat luva) untuk mengenal pasti punca kaki anaknya \\
& yang sakit secara tiba-tiba. Setelah itu, barulah diketahui bahawa si Majina \\
& sakit kaki kerana telah terlangkah pohon nanas yang telah ditanami 'sejenis \\
& barang yang telah dijampi orang'. Setelah mengenal pasti puncanya, ibu \\
& Majina pun membawanya berjumpa dengan seorang bomoh tua yang \\
& tinggal di seberang Sungai Padas untuk diubati dan dia akhirnya dapat \\
& berjalan seperti biasa.
\end{tabular}

15. MR15 Terdapat seorang perempuan Murut yang telah jatuh sakit akibat memanjat pokok manggis. Dikisahkan bahawa setelah beberapa lama berada di atas pokok manggis, si perempuan tiba-tiba berteriak dan mengejutkan semua orang yang berada di sana. Setelah itu, beberapa orang pakciknya yang kebetulan berada di situ pun memanjat pohon manggis dan membawanya turun. Sebaik sahaja sampai di bawah, tubuh si perempuan telah membengkak, menjadi kemerah-merahan dan dia mula mengigil. Kesemua pakciknya pun bergegas membawanya ke hospital menggunakan perahu. Walaupun telah diberi makan ubat dan diberi suntikan, namun keadaan si perempuan tetap sama. Akhirnya dia terpaksa dibawa pulang dan dibawa berjumpa dengan seorang bomoh yang tinggal di Patian (sebuah kampung di Kemabong). Setelah diperiksa, bomoh tersebut memberitahu mereka bahawa si perempuan itu telah diganggu oleh semangat aru (semangat dalam bentuk ular). Bomoh berkenaan pun memandikan si perempuan dengan air Sungai Padas yang telah dijampi dan ditabur dengan tanah. Pada keesokan harinya, si perempuan pun kembali sihat dan boleh berjalan seperti biasa.

16. MR16 Terdapat seorang lelaki yang sakit kepala sehingga dia tidak dapat tidur. Bapanya menjalankan amalan antutup (amalan untuk mencari punca penyakit dengan mengetuk mangkuk yang berisi air dengan dua kerat luva) dan mendapati ia telah keteguran oleh seorang lelaki tua. Sakit kepala lelaki ini sembuh setelah diubati dengan menggunakan sepotong rambut lelaki tua yang menegurnya. 


\begin{tabular}{lll}
\hline Bil. & Memorat & Ringkasan cerita \\
\hline 17. & MR17 & Mengisahkan seorang bayi yang telah diganggu oleh semangat setelah \\
& beberapa bulan dilahirkan. Bayi ini telah dibawa oleh ibunya pergi ke \\
& klinik berjumpa doktor, tetapi dia tetap menangis tidak henti-henti. Seorang \\
& kawan yang mengetahui cara mengubati penyakit ini menyuruh datuk \\
& bayi tersebut mengambil beberapa helai daun pamamavas ra inupi (daun \\
& senduduk hutan) dan kusul taniou (jerangau) di dalam hutan. Apabila daun \\
& itu telah kering, si datuk pun membakar daun tersebut dan mengenakan \\
& asapnya di badan cucunya. Daun yang masih hijau pula disisipkan di \\
& bawah kepala cucunya. Perkara tersebut diulangi sebanyak beberapa kali \\
& dalam satu malam selama empat hari berturut-turut. Bau asap daripada \\
& daun pamamavas ra inupi dan kusul taniou telah menakutkan semangat \\
& yang menganggunya. Akhirnya, bayi tersebut pun sembuh.
\end{tabular}

18. MR18 Terdapat sekumpulan kanak-kanak lelaki yang mempermain-mainkan haiwan dan serangga. Mereka telah mencucuk belakang penyengat dengan menggunakan bulu ayam. Setelah itu, penyengat tersebut diterbangkan dan dilontar dengan menggunakan batu sambil mereka ketawa terbahakbahak. Pada keesokan harinya, tangan dan kaki salah seorang kanak-kanak tersebut menjadi bengkok dan tidak dapat diluruskan lagi. Secara tibatiba, cuaca pada hari itu juga berubah menjadi buruk. Dipercayai bahawa semangat buhang (semangat penjaga haiwan) telah datang membalas dendam kerana kanak-kanak itu mempermain-mainkan dan menyakitkan penyengat. Semakin lama, tangan dan kaki kanak-kanak tersebut juga menjadi semakin kecil. Hanya setelah hampir sebulan si aki Andimau (bomoh) mengubatinya, barulah penyakit ganjil kanak-kanak itu dapat disembuhkan.

19. MR19 Pada suatu hari, seorang wanita tidak dapat berjalan secara tiba-tiba dan berlanjutan selama enam bulan. Walaupun dia dibawa ke rumah sakit Kemabong dan Hospital Tenom, namun doktor tidak menemui punca yang menyebabkan kakinya sakit. Salah seorang lelaki di kampung tersebut telah memberitahu anak-anaknya supaya membawa ibu mereka berjumpa dengan si Ambului, seorang bomoh. Semasa mengubati si ibu, si Ambului hanya menggunakan sudu, tanah dan gelas kaca sahaja. Setelah diubati, terdapat batu yang berdarah dan bernanah di kaki si pesakit yang telah ditarik keluar oleh si Ambului. Akhirnya, wanita tersebut dapat berjalan seperti biasa. 


\section{Lampiran 3}

\section{Memorat yang berkait dengan perubatan fizikal etnik Murut Tahol}

\begin{tabular}{lll}
\hline Bil. & Memorat & Ringkasan cerita \\
\hline 1. & MF1 & Seorang ibu telah menggunakan luva untuk mengubati pusat bayinya \\
& yang bengkak, berair dan berwarna kemerah-merahan setelah tiga bulan \\
& dilahirkan. Apabila dibawa ke hospital, ubat sapu yang diberikan oleh \\
& doktor tidak berkesan untuk menghilangkan sakit di pusat bayinya. \\
& Akhirnya si ibu pun memutuskan untuk membawa bayinya berjumpa \\
& dengan seorang bomoh yang bernama Latau. Setelah diperiksa, Latau \\
& memberitahunya bahawa terdapat sejenis 'benda' melekat di dalam pusat \\
& bayi tersebut. Benda tersebut tidak dapat dilihat oleh orang lain kecuali \\
& bayinya sendiri. Setelah itu, Latau pun mengajar si ibu agar menjemur dan \\
& selepas itu membakar batang luva sehingga menjadi arang. Kemudian, \\
& arang luva yang telah sejuk diletakkan di sekeliling pusat bayi mengikut \\
& arah pusingan jam. Bomoh Latau menyuruh si ibu supaya melakukannya \\
& berulang-ulang kali selama beberapa hari. Akhirnya, pusat bayi itu pun \\
& pulih semula.
\end{tabular}

2. MF2

Seorang gadis di kampung menghidapi penyakit gatal di seluruh tubuhnya sebaik sahaja dia pulang bekerja dari kebun kopinya. Apabila ubat gatal yang diberikan oleh doktor juga tidak berkesan, ibunya menyuruh dia pergi mencari daun talirus yang kering untuk dijadikan ubat gatal. Setelah daun talirus dibakar dan diasapkan di seluruh badan si pesakit, gatal di tubuhnya pun terus hilang.

\begin{tabular}{ll}
\hline 3. MF3 & Terdapat seorang lelaki di kampung menderita kerana menghidapi \\
& penyakit batu karang yang menyebabkannya kencing berdarah. Menurut \\
& doktor yang memeriksanya, penyakit batu karang lelaki tersebut berada \\
& pada tahap serius dan perlu dibedah dalam tempoh tiga hari. Walaupun \\
& tinggal di wad hospital, namun si lelaki juga diberi minum air yang \\
& direbus dengan daun pangancur vatu pada setiap pagi, tengah hari, petang \\
& dan malam. Pada hari yang ketiga, si lelaki tidak jadi dibedah kerana batu \\
& karang yang terdapat di dalam perutnya sudah tidak ada.
\end{tabular}

4. MF4 Kisah ini mengisahkan si Pilaus yang menghidapi sakit bisul di kakinya. Bisulnya bernanah dan menyebabkan dia berasa sangat gatal. Si Pilaus pergi ke tebing Sungai Padas untuk memetik daun rumput tahi ayam lalu melumatkannya dengan menggunakan tapak tangan. Daun rumput tahi ayam yang telah dilumatkannya itu telah dilekatkannya pada permukaan bisul di kakinya dan dibiarkan di situ selama beberapa saat. Ketika bisulnya dirasakan berdenyut, dia pun menarik daun rumput tahi ayam pada permukaan kakinya dengan pantas. Sewaktu daun tersebut ditarik, nanah bisul yang melekat pada daun tersebut turut ditarik keluar. Dengan menggunakan kaedah ini, sakit bisul di kakinya pun sembuh. 


\begin{tabular}{lll}
\hline Bil. & Memorat & Ringkasan cerita \\
\hline 5. & MF5 & Mengisahkan seorang lelaki Tahol di Kampung Rumuli yang menghidapi \\
& sakit pinggang secara tiba-tiba. Penyakit ini menyebabkan dia tidak dapat \\
& duduk atau baring. Adakalanya, dia terpaksa menahan kesakitannya \\
& dengan mengikat sehelai tuala di pinggangnya. Terdapat saudara-maranya \\
& yang mencadangkan agar dia pergi berubat dengan seorang bomoh \\
& kampung kerana dikhuatiri penyakitnya berpunca daripada buatan orang. \\
& Semasa dibawa berjumpa dengan bomoh, si pesakit telah diberi minum \\
& segelas air yang telah dijampi. Sejenis akar yang tebal juga digunakan \\
& untuk melilit pinggang si pesakit selama empat jam. Setelah itu, sakit \\
& pinggang lelaki itu pun sembuh. \\
\hline MF6 & Seorang lelaki Murut di Kampung Tolokoson telah mengalami luka di \\
& kakinya. Pada waktu itu, dia dan isterinya sedang menebas hutan untuk \\
& dijadikan tempat menanam padi bukit. Sewaktu sedang mengapak \\
& pokok, lelaki Murut ini tiba-tiba terkapak kakinya secara tidak sengaja. \\
& Oleh sebab darah mengalir dengan banyak, si isteri dengan pantas pergi \\
& memetik daun sirih hutan yang menjalar pada pokok yang berdekatan. \\
& Daun sirih dilumatkannya dengan menggunakan tapak tangan dan \\
& dilekatkan pada luka kaki suaminya. Luka di kaki suaminya pun diikat \\
& dengan menggunakan kulit kayu. Sebulan kemudian, lukanya sembuh \\
& kembali dan si pesakit dapat berjalan seperti biasa. \\
\hline
\end{tabular}

\section{Rujukan}

Abd. Hakim Mohad. 2014. Spiritual journey of Murut Tahol in Sabah and its effect to their headhunting practice. International Journal of Social Science and Humanity 4(6): 426-429, https://doi.org/10.7763/IJSSH.2014.V4.392

Arba'iyah Mohd Noor. 2014. Menyingkap ilmu perubatan Melayu menerusi beberapa manuskrip terpilih. Jurnal Sejarah 22(1): 140-168.

Aripin Said. 1996. Prosa warisan. Kuala Lumpur: Dewan Bahasa dan Pustaka.

Charles, I.S. 2003. Healing in Sabah: Mysteries of illness and well-being. Kota Kinabalu: Sabah Museum.

Danandjaya, J. 2002. Folklor Indonesia: Ilmu gosip, dongeng dan lain-lain. Jakarta: Grafiti.

Fatan Hamamah Hj. Yahya. 2003. Potensi tumbuh-tumbuhan sebagai ubat-ubatan. Jurnal e-bangi. Retrieved 26 April 2017 from https://core.ac.uk/download/pdf/14330177. pdf

Foo, J. 2014. Faktor kelangsungan pasaran tumbuhan ubatan di tamu Pantai Barat Sabah: Satu tinjauan awal. Malaysian Journal of Society and Space 10(2): 115-126.

Fung, J.M. 2003. The Muruts: Spiritual world, rituals and shamanism. Journal of Sabah Society 20: 15-23.

Hamidah Abdul Wahab. 2013. Petua dan pantang larang tradisional dalam alam Melayu Sarawak. International Journal of the Malay World and Civilisation 1(1): 89-97.

Harun Mat Piah. 2003. Sastera rakyat Malaysia, Indonesia, Negara Brunei Darussalam: Suatu perbandingan. Kuala Lumpur: Dewan Bahasa dan Pustaka.

Haviland, W.A. 1993. Antropologi Jilid 1. Jakarta: Erlangga. 
Ismail Ibrahim. 2007. Murut: Menyusuri budaya dan kewujudan masyarakat awal di Sabah. In Saidatul Nornis Hj. Mahali, Mohd Sarim Hj. Mustajab and Suraya Sintang, eds. Pluraliti etnik dan budaya di Sabah (pp. 63-117). Kota Kinabalu: Penerbit Universiti Malaysia Sabah.

. 2012. Warisan motif dan corak etnik Sabah. Kota Kinabalu: Penerbit Universiti Malaysia Sabah.

Kulip, J. 2003. An ethnobotanical survey of medicinal and other useful plants of Muruts in Sabah, Malaysia. Telopea 10(1): 81-98, https://doi.org/10.7751/telopea20035608 2005. Similarity of medicinal plants used by two native communities in Sabah, Malaysia. Bioprospecting \& Ethnopharmacology 1: 81-85, https://doi.org/10.17660/ ActaHortic.2005.675.10

Low, K.O. 2005. Membaca mitos dan legenda Kadazandusun. Bangi: Penerbit Universiti Kebangsaan Malaysia.

Low, K.O. and Sri Ningsih. 2013. Pandangan dunia dan konteks upacara dalam Sumazau Penampang, Sazau Papar dan Sumazau Paina Membakut. Akademika 83(2\&3): 47-59.

Low, K.O. and Azlan Shafie Abdullah. 2014. Bbahul dan hubungannya dengan kepercayaan Bbiruhui etnik Rungus di Sabah. Kemanusiaan 21(1):73-102

Mohd. Nizam Sahad. 2015. Penggunaan azimat pelaris perniagaan menurut perspektif akidah Islam. Jurnal Antarabangsa Dunia Melayu 8(1): 18-44.

Mohd. Taib Othman. 1982. Manual for collecting oral tradition with special reference to South East Asia. Kuala Lumpur: Dewan Bahasa dan Pustaka.

Mohd. Taib Osman. 1988. Bunga rampai kebudayaan Melayu. Kuala Lumpur: Dewan Bahasa dan Pustaka.

. 1991. Pengkajian sastera rakyat bercorak cerita. Kuala Lumpur: Percetakan Rina Sdn. Bhd.

Norlizawati Md. Nor and Rahimah A. Hamid. 2013. Kearifan tempatan dalam memanfaatkan sumber alam untuk perubatan tradisional. In Kearifan tempatan pengalaman nusantara, Jilid 1: Berasal dari akar, eds. Nazarudin Zainun, Rahimah A. Hamid and Mohd Kipli Abdul Rahman (pp. 131-154). Pulau Pinang: Penerbit Universiti Sains Malaysia.

Patthira Phon-ngam. 2013. A development of healthy promotion model by E-SAN Folk Healer's wisdom. Journal of Social Sciences (COES \& RJ-JSS) 2(2): 5-14.

Pugh-Kitingan, J. 2012. Murut. In Murut dan pelbagai etnik kecil lain di Sabah, eds. K Mariappan and P. Porodong (pp. 23-107). Kuala Lumpur: Institut Terjemahan dan Buku Malaysia.

Saad Othman, Zuraidah Mohd Yusoff and Adenan Jaafar. 2013. Perubatan tradisional Melayu: Konsep dan amalan. In Kearifan tempatan pengalaman nusantara, Jilid 1: Berasal dari akar, eds. Nazarudin Zainun, Rahimah A. Hamid and Mohd Kipli Abdul Rahman (pp. 155-180). Pulau Pinang: Penerbit Universiti Sains Malaysia.

Toelken, B. 1996. The dynamics of folklore. Logan, Utah: Utah State University Press.

Woolley, G.C. 1928. Murut folktales. Folklore 39(3): 253-271.

Yoserizal and Jamaluddin Md. Jahi. 2012. Sistem perubatan tradisional orang petalangan yang terhakis di kabupaten Pelalawan, Provinsi Riau, Indonesia. International Journal of the Malay World and Civilisation 30(1): 197-214. 